\title{
The Effect of Diabetes Self-Management Education (DSME) on Improving Self-Management and Quality of Life in Millitus Type 2 Diabetes
}

\author{
Reza Diko Utama ${ }^{1}$, Indasah ${ }^{2}$, \\ Siti Farida Noor Layla ${ }^{3}$ \\ ${ }^{1}$ Health Promotion, Public \\ Health, IIK STRADA \\ INDONESIA \\ ${ }^{2}$ Health Promotion, Public \\ Health, IIK STRADA \\ INDONESIA \\ ${ }^{3}$ Health Promotion, Public \\ Health, IIK STRADA \\ INDONESIA \\ Email: \\ rezadiko13@gmail.com
}

Received : January $1^{\text {st }} 2021$

Accepted : May 3th 2021

Published : May $20^{\text {th }} 2021$

\section{ABSTRACT}

Self-management is a form of self-management or selfregulation which includes knowledge and skills in self-management. Quality of life is the level where individuals can maximize the physical and psychological functioning of life. This research method is True-Experiment with Pre-Test and Post-Test designs. The research instruments were DSMQ and WHOQOL. Independent Variables, Daiabetes Self-Management Education (DSME) Dependent Variables Self-management and quality of life. Subjects were divided into two, namely the control group totaling 55 people and the intervention group amounting to 55 people using simple random sampling technique. Data analysis using Wilcoxon and Maan-Whitney. The results of the comparison of self-management in the intervention group and the control group obtained a significance value of 0.000 less than 0.05 ( $p<0.05)$ indicating that the group given the intervention was more effective at improving self-management significantly than the group that was not given the intervention. The results of the comparison of the quality of life variables of the intervention group and the control group obtained a significance value of 0.000 less than 0.05 ( $p<0.05$ ), which indicates that the group given the intervention was more effective in improving the quality of life significantly compared to the group that was not given the intervention.

Keywords: Education, Self-Management, Quality of Life, Diabetes Mellitus

Copyright @ 2021 IIK STRADA Indonesia All right reserved.

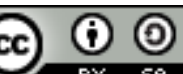

This is an open-acces article distributed under the terms of the Creative Commons Attribution-ShareAlike 4.0 International License.

\section{INTRODUCTION}

Non-Communicable Diseases (PNM) has become a public health problem, in recent years Non-Communicable Disease (PNM) has emerged as a key public health problem due to the high number of deaths worldwide caused by Non-Communicable Diseases (PNM), a non-communicable disease. Contagious that has received a lot of attention is Diabetes Millitus Type 2 (Pham et al., 2019). People with Type 2 Diabetes Millitus often do not have the knowledge, skills and abilities in carrying out self-management or Self-Management. Diabetes Millitus self-management behavior is very little people understand, because there are internal and external obstacles. Patients with Type 2 Diabetes Millitus still do not understand the importance of modifying self-care such as diabetes millitus diet, diabetes millitus diet, diabetes millitus physical activity, and blood sugar control are part of Diabetes Millitus self-management (Whittemore et al., 2019). Self-management is self-management of how a person can and must manage themselves so that in becoming a 
successful self in their life span, someone will experience confusion about themselves, who they are and how others see themselves, someone can assess themselves multidimensional and manage themselves , 2015).

\section{MATERIALS AND METHODS}

This research method is True-Experiment with Pre-Test and Post-Test designs. The research instruments were the DSMQ and WHOQOL. Independent Variables, Daiabetes Self-Management Education (DSME) Dependent Variables Self-management and quality of life. Subjects were divided into two, namely the control group totaling 55 people and the intervention group amounting to 55 people using simple random sampling technique. Data analysis using Wilcoxon and Maan-Whitney.

\section{RESULTS}

From the results of research conducted by researchers can be seen in the table as follow:

Tabel 1. Self-Management of Patients with Type II Diabetes Mellitus Comparison of Pre and Post Test in the Control Group

\begin{tabular}{|c|c|c|c|c|c|c|}
\hline Variabel & & $\mathbf{M}$ & SD & $\mathbf{Z}$ & Sig. & Ket \\
\hline \multirow{2}{*}{ Diabetes Diet and Diet } & Pre test & 1.127 & 0.742 & \multirow{2}{*}{-0.627} & \multirow{2}{*}{0.531} & \multirow{2}{*}{ Tidak } \\
\hline & Post test & 1.109 & 0.754 & & & \\
\hline \multirow{2}{*}{$\begin{array}{l}\text { Exercise / } \\
\text { Diabetes }\end{array}$} & ActivityPre test & 1.025 & 0.767 & \multirow{2}{*}{-1.796} & \multirow{2}{*}{0.072} & \multirow{2}{*}{ Tidak } \\
\hline & Post test & 1.079 & 0.778 & & & \\
\hline \multirow{2}{*}{ Diabetes Blood Sugar Control } & Pre test & 1.167 & 0.766 & \multirow{2}{*}{-1.224} & \multirow{2}{*}{0.221} & \multirow{2}{*}{ Tidak } \\
\hline & Post test & 1.193 & 0.796 & & & \\
\hline \multirow{2}{*}{ Diabetes Health Care } & Pre test & 1.135 & 0.774 & \multirow{2}{*}{-1.721} & \multirow{2}{*}{0.085} & \multirow{2}{*}{ Tidak } \\
\hline & Post test & 1.195 & 0.790 & & & \\
\hline \multirow{2}{*}{ Thorough Care } & Pre test & 0.745 & 1.004 & \multirow{2}{*}{-0.322} & \multirow{2}{*}{0.748} & \multirow{2}{*}{ Tidak } \\
\hline & Post test & 0.764 & 0.962 & & & \\
\hline \multirow{2}{*}{ Self-Management } & Pre test & 1.099 & 0.692 & \multirow{2}{*}{-2.198} & \multirow{2}{*}{0.028} & \multirow{2}{*}{ Signifikan } \\
\hline & Post test & 1.125 & 0.702 & & & \\
\hline
\end{tabular}

The results of the comparison of the pre-test and post-test values on the dietary pattern and diabetes diet variables in the control group obtained a significance value of 0.531 and more than 0.05 ( $p>0.05$ ) which indicates that there is no significant increase in diet and diabetes diet without giving it. intervention. The results of the comparison of the pre-test and post-test values on the sports / physical activity variables of diabetes in the control group obtained a significance value of 0.072 and more than 0.05 ( $p>0.05$ ), which indicates that there was no significant increase in sports / physical activity without giving diabetes. intervention. The results of the comparison of the pre-test and post-test values on the control variable diabetes blood sugar in the control group obtained a significance value of 0.221 and more than 0.05 ( $>>0.05$ ), which indicates that there was no significant increase in diabetes blood sugar control without intervention. The results of the comparison of the pre-test and post-test scores on the diabetes health care variables in the control group obtained a significance value of 0.085 and more than $0.05(\mathrm{p}>0.05)$, which indicates that there was no significant increase in diabetes health care without intervention. The results of the comparison of the pre-test and post-test scores on the overall care variable in the control group obtained a significance value of 0.748 and more than $0.05(p>0.05)$, which indicates that there was no significant increase in overall care without intervention. The results of the comparison of the pretest and post-test values on the self-management variable in the control group obtained a significance value of 0.028 and less than $0.05(\mathrm{p}<0.05)$ which indicates a small amount of improvement in self-management. 
Tabel 2. Quality of Life for Patients with Type II Diabetes Mellitus Comparison of Pre-Test and Post in the Control Group

\begin{tabular}{|c|c|c|c|c|c|c|}
\hline Variabel & & $\mathbf{M}$ & SD & $\mathbf{Z}$ & Asymp Sig. & Significancy \\
\hline \multirow{2}{*}{ Physical Health } & Pre test & 1.979 & 0.996 & \multirow{2}{*}{-1.601} & \multirow{2}{*}{0.109} & \multirow{2}{*}{ No } \\
\hline & Post test & 2.012 & 0.981 & & & \\
\hline \multirow{2}{*}{ Psychology } & Pre test & 2.185 & 0.985 & \multirow{2}{*}{-0.759} & \multirow{2}{*}{0.448} & \multirow[t]{2}{*}{ No } \\
\hline & Post test & 2.204 & 1.012 & & & \\
\hline \multirow{2}{*}{ Social } & Pre test & 2.280 & 0.924 & \multirow{2}{*}{-1.341} & \multirow{2}{*}{0.180} & \multirow[t]{2}{*}{ No } \\
\hline & Post test & 2.240 & 0.922 & & & \\
\hline \multirow{2}{*}{ Environment } & Pre test & 1.979 & 0.892 & \multirow{2}{*}{-1.493} & \multirow{2}{*}{0.135} & \multirow[t]{2}{*}{ No } \\
\hline & Post test & 1.943 & 0.928 & & & \\
\hline \multirow{2}{*}{ Thorough } & Pre test & 2.336 & 1.093 & \multirow{2}{*}{-0.791} & \multirow{2}{*}{0.429} & \multirow[t]{2}{*}{ No } \\
\hline & Post test & 2.364 & 1.120 & & & \\
\hline \multirow{2}{*}{ Quality of Life } & Pre test & 2.099 & 0.892 & \multirow{2}{*}{-0.169} & \multirow{2}{*}{0.866} & \multirow[t]{2}{*}{ No } \\
\hline & Post test & 2.099 & 0.908 & & & \\
\hline
\end{tabular}

The results of the comparison of the pre-test and post-test scores on the physical health variables in the control group obtained a significance value of 0.109 and more than 0.05 ( $p>0.05$ ), which indicates that there was no significant increase in physical health without intervention. The results of the comparison of the pre-test and post-test scores on psychological variables in the control group obtained a significance value of 0.448 and more than 0.05 ( $p>0.05)$ which indicates that there is no significant psychological improvement without the intervention. The results of the comparison of the pre-test and post-test scores on social variables in the control group obtained a significance value of 0.180 and more than 0.05 ( $p>0.05$ ), which indicates no significant social improvement without intervention. The results of the comparison of the pre-test and post-test values for environmental variables in the control group obtained a significance value of 0.135 and more than 0.05 ( $p>0.05$ ), which indicates that there is no significant environmental improvement without intervention. The results of the comparison of the pre-test and post-test scores on the overall variables in the control group obtained a significance value of 0.429 and more than 0.05 ( $p>0.05$ ), which indicates that there was no significant overall increase without intervention. The results of the comparison of the pre-test and post-test scores on the quality of life variable in the control group obtained a significance value of 0.866 and more than 0.05 ( $p>0.05)$, which indicates that there was no significant increase in quality of life without intervention.

Tabel 3. Self-Management of Patients with Type II Diabetes Mellitus Comparison of Pre and Post Test in the Intervention Group

\begin{tabular}{|c|c|c|c|c|c|c|}
\hline Variabel & & $\mathbf{M}$ & SD & $\mathbf{Z}$ & Asymp Sig. & Significancy \\
\hline \multirow{2}{*}{ Diabetes Diet and Diet } & Pre test & 1.477 & 0.775 & \multirow{2}{*}{-5.561} & \multirow{2}{*}{0.000} & \multirow{2}{*}{ Sig } \\
\hline & Post test & 2.491 & 0.821 & & & \\
\hline \multirow{2}{*}{$\begin{array}{l}\text { Exercise / Physical Activity } \\
\text { Diabetes }\end{array}$} & Pre test & 1.431 & 0.921 & \multirow{2}{*}{-5.226} & \multirow{2}{*}{0.000} & \multirow[t]{2}{*}{ Sig } \\
\hline & Post test & 2.485 & 0.812 & & & \\
\hline \multirow{2}{*}{ Diabetes Blood Sugar Control } & Pre test & 1.367 & 0.773 & \multirow{2}{*}{-5.860} & \multirow{2}{*}{0.000} & \multirow[t]{2}{*}{ Sig } \\
\hline & Post test & 2.458 & 0.900 & & & \\
\hline \multirow{2}{*}{ Diabetes Health Care } & Pre test & 1.418 & 0.792 & \multirow{2}{*}{-5.845} & \multirow{2}{*}{0.000} & \multirow[t]{2}{*}{ Sig } \\
\hline & Post test & 2.539 & 0.803 & & & \\
\hline \multirow{2}{*}{ Thorough Care } & Pre test & 1.436 & 0.996 & \multirow{2}{*}{-4.983} & \multirow{2}{*}{0.000} & \multirow[t]{2}{*}{ Sig } \\
\hline & Post test & 2.491 & 0.979 & & & \\
\hline \multirow{2}{*}{ Self-Management } & Pre test & 1.421 & 0.734 & \multirow{2}{*}{-6.128} & \multirow{2}{*}{0.000} & \multirow[t]{2}{*}{ Sig } \\
\hline & Post test & 2.490 & 0.820 & & & \\
\hline
\end{tabular}

The results of the comparison of the pre-test and post-test values on the variable dietary diet and diabetes diet in the intervention group obtained a significance value of 0.000 and less than 0.05 $(\mathrm{p}<0.05)$ which indicates a significant increase in dietary patterns and diabetic diet with the intervention. The results of the comparison of the pre-test and post-test values on the sports / physical activity variables of diabetes in the intervention group obtained a significance value of 
0.000 and less than $0.05(\mathrm{p}<0.05)$ which indicates a significant increase in sports / physical activity with diabetes with the intervention. . The results of the comparison of the pre-test and post-test values on the control variable diabetes blood sugar in the intervention group obtained a significance value of 0.000 and less than $0.05(\mathrm{p}<0.05)$ which indicates a significant increase in diabetes blood sugar control with the intervention. The results of the comparison of the pre-test and post-test values on the diabetes health care variable in the intervention group obtained a significance value of 0.000 and less than $0.05(\mathrm{p}<0.05)$ which indicates a significant increase in diabetes health care with the provision of intervention. The results of the comparison of the pre-test and post-test scores on the overall care variable in the intervention group obtained a significance value of 0.000 and less than $0.05(\mathrm{p}<0.05)$ which indicates a significant increase in overall care with the intervention. The results of the comparison of the pre-test and post-test scores on the self-management variable in the intervention group obtained a significance value of 0.000 and less than $0.05(\mathrm{p}<0.05)$ which indicates a significant increase in self-management with the provision of intervention

Tabel 4. Quality of Life for Patients with Type II Diabetes Mellitus Comparison of Pre and Post Test in the Intervention Group

\begin{tabular}{|c|c|c|c|c|c|c|}
\hline Variabel & & $\mathbf{M}$ & SD & $\mathbf{Z}$ & Asymp Sig. & Significancy \\
\hline \multirow{2}{*}{ Physical Health } & Pre test & 2.148 & 1.280 & \multirow{2}{*}{-5.689} & \multirow{2}{*}{0.000} & \multirow[t]{2}{*}{ Sig } \\
\hline & Post test & 3.720 & 1.477 & & & \\
\hline \multirow{2}{*}{ Psychology } & Pre test & 2.429 & 0.952 & \multirow{2}{*}{-5.831} & \multirow{2}{*}{0.000} & \multirow[t]{2}{*}{ Sig } \\
\hline & Post test & 3.655 & 1.182 & & & \\
\hline \multirow{2}{*}{ Social } & Pre test & 2.385 & 1.160 & \multirow{2}{*}{-5.552} & \multirow{2}{*}{0.000} & \multirow[t]{2}{*}{ Sig } \\
\hline & Post test & 3.273 & 1.021 & & & \\
\hline \multirow{2}{*}{ Environment } & Pre test & 2.205 & 1.063 & \multirow{2}{*}{-4.893} & \multirow{2}{*}{0.000} & \multirow[t]{2}{*}{ Sig } \\
\hline & Post test & 2.780 & 1.072 & & & \\
\hline \multirow{2}{*}{ Thorough } & Pre test & 2.727 & 1.018 & \multirow{2}{*}{-5.404} & \multirow{2}{*}{0.000} & \multirow[t]{2}{*}{ Sig } \\
\hline & Post test & 3.964 & 1.258 & & & \\
\hline \multirow{2}{*}{ Quality of Life } & Pre test & 2.331 & 1.062 & \multirow{2}{*}{-5.952} & \multirow{2}{*}{0.000} & \multirow[t]{2}{*}{ Sig } \\
\hline & Post test & 3.392 & 1.165 & & & \\
\hline
\end{tabular}

The results of the comparison of the pre-test and post-test values on the physical health variables in the intervention group obtained a significance value of 0.000 and less than 0.05 (p $<0.05$ ), which indicates a significant increase in physical health with the intervention. The results of the comparison of the pre-test and post-test scores on psychological variables in the intervention group obtained a significance value of 0.000 and less than $0.05(\mathrm{p}<0.05)$ which indicates a significant psychological improvement with the intervention. The results of the comparison of the pre-test and post-test scores on social variables in the intervention group obtained a significance value of 0.000 and less than $0.05(\mathrm{p}<0.05)$, which indicates a significant social improvement with the intervention. The results of the comparison of the pre-test and post-test scores on environmental variables in the intervention group obtained a significance value of 0.000 and less than $0.05(\mathrm{p}$ $<0.05$ ) which indicates a significant increase in the environment with the provision of intervention. The results of the comparison of the pre-test and post-test scores on the overall variables in the intervention group obtained a significance value of 0.000 and less than $0.05(\mathrm{p}<0.05)$ which indicates a significant overall increase with the provision of the intervention. The results of the comparison of the pre-test and post-test scores on the quality of life variable in the intervention group obtained a significance value of 0.000 and less than $0.05(\mathrm{p}<0.05)$ which indicates a significant increase in the quality of life with the intervention. 
The Effect of Diabetes Self-Management Education (DSME).....

Table 5. Self-Management of Patients with Type II Diabetes Mellitus Comparison of Control and Intervention Groups

\begin{tabular}{|c|c|c|c|c|c|c|}
\hline Variabel & & $\mathbf{M}$ & SD & $\mathbf{Z}$ & Asymp Sig. & Significancy \\
\hline \multirow{2}{*}{ Diabetes Diet and Diet } & Intervensi & 2.491 & 0.821 & \multirow{2}{*}{-6.763} & \multirow{2}{*}{0.000} & \multirow[t]{2}{*}{ Sig } \\
\hline & Kontrol & 1.109 & 0.754 & & & \\
\hline \multirow{2}{*}{ Exercise / Physical Activity Diabetes } & Intervensi & 2.485 & 0.812 & \multirow{2}{*}{-6.732} & \multirow{2}{*}{0.000} & \multirow[t]{2}{*}{ Sig } \\
\hline & Kontrol & 1.079 & 0.778 & & & \\
\hline \multirow{2}{*}{ Diabetes Blood Sugar Control } & Intervensi & 2.458 & 0.900 & \multirow{2}{*}{-6.231} & \multirow{2}{*}{0.000} & \multirow[t]{2}{*}{ Sig } \\
\hline & Kontrol & 1.193 & 0.796 & & & \\
\hline \multirow{2}{*}{ Diabetes Health Care } & Intervensi & 2.539 & 0.803 & \multirow{2}{*}{-6.986} & \multirow{2}{*}{0.000} & \multirow[t]{2}{*}{ Sig } \\
\hline & Kontrol & 1.195 & 0.790 & & & \\
\hline \multirow{2}{*}{ Thorough Care } & Intervensi & 2.491 & 0.979 & \multirow{2}{*}{-6.824} & \multirow{2}{*}{0.000} & \multirow[t]{2}{*}{ Sig } \\
\hline & Kontrol & 0.764 & 0.962 & & & \\
\hline \multirow{2}{*}{ Self-Management } & Intervensi & 2.490 & 0.820 & \multirow{2}{*}{-7.430} & \multirow{2}{*}{0.000} & \multirow[t]{2}{*}{ Sig } \\
\hline & Kontrol & 1.125 & 0.702 & & & \\
\hline
\end{tabular}

The results of the comparison of the variable dietary diet and diabetes diet between the intervention group and the control group obtained a significance value of 0.000 and less than 0.05 (p $<0.05$ ), which indicates that the group given the intervention was more effective in improving the diabetes diet and diet significantly. compared with the group not given the intervention. The results of the comparison of the diabetes exercise / physical activity variable between the intervention group and the control group obtained a significance value of 0.000 and less than $0.05(\mathrm{p}<0.05)$, which indicates that the group given the intervention was more effective at increasing diabetes exercise / physical activity significantly. compared with the group not given the intervention. The results of the comparison of the diabetes blood sugar control variable between the intervention group and the control group obtained a significance value of 0.000 and less than $0.05(\mathrm{p}<0.05)$, which indicates that the group given the intervention was more effective at improving diabetes blood sugar control significantly compared to the group that was not given the intervention. on the diabetes health care variable between the intervention group and the control group, a significance value of 0.000 and less than $0.05(\mathrm{p}<0.05)$ was obtained, which indicates that the group given the intervention was more effective at improving diabetes health care significantly compared to the group that was not given intervention. The results of the comparison of the post-test scores on the overall care variable between the intervention group and the control group obtained a significance value of 0.000 and less than $0.05(\mathrm{p}<0.05)$, which indicates that the group given the intervention was more effective at increasing overall care significantly compared to the who were not given the intervention. The results of the comparison of the self-management variable between the intervention group and the control group obtained a significance value of 0.000 and less than $0.05(\mathrm{p}<0.05)$, which indicates that the group given the intervention was more effective at improving self-management significantly compared to the group that was not given. intervention.

Tabel 6. Quality of Life of Patients with Type II Diabetes Mellitus Comparison in Control and Intervention Group

\begin{tabular}{|c|c|c|c|c|c|c|}
\hline Variabel & & $\mathbf{M}$ & SD & $\mathbf{Z}$ & Asymp Sig. & Significancy \\
\hline \multirow{2}{*}{ Physical Health } & Intervensi & 3.720 & 1.477 & \multirow{2}{*}{-5.272} & \multirow{2}{*}{0.000} & \multirow[t]{2}{*}{ Sig } \\
\hline & Kontrol & 2.012 & 0.981 & & & \\
\hline \multirow{2}{*}{ Psychology } & Intervensi & 3.655 & 1.182 & \multirow{2}{*}{-5.661} & \multirow{2}{*}{0.000} & \multirow[t]{2}{*}{ Sig } \\
\hline & Kontrol & 2.204 & 1.012 & & & \\
\hline \multirow[t]{2}{*}{ Social } & Intervensi & 3.273 & 1.021 & \multirow{2}{*}{-5.239} & \multirow{2}{*}{0.000} & \multirow[t]{2}{*}{ Sig } \\
\hline & Kontrol & 2.240 & 0.922 & & & \\
\hline \multirow{2}{*}{ Environment } & Intervensi & 2.780 & 1.072 & \multirow{2}{*}{-4.528} & \multirow{2}{*}{0.000} & \multirow[t]{2}{*}{ Sig } \\
\hline & Kontrol & 1.943 & 0.928 & & & \\
\hline \multirow{2}{*}{ Thorough } & Intervensi & 3.964 & 1.258 & \multirow{2}{*}{-5.925} & \multirow{2}{*}{0.000} & \multirow[t]{2}{*}{ Sig } \\
\hline & Kontrol & 2.364 & 1.120 & & & \\
\hline \multirow{2}{*}{ Quality of Life } & Intervensi & 3.392 & 1.165 & \multirow{2}{*}{-5.236} & \multirow{2}{*}{0.000} & \multirow[t]{2}{*}{ Sig } \\
\hline & Kontrol & 2.099 & 0.908 & & & \\
\hline
\end{tabular}


The results of the comparison of the physical health variables between the intervention group and the control group obtained a significance value of 0.000 and less than 0.05 ( $p<0.05)$, which indicates that the group given the intervention was more effective at improving physical health significantly than the group that was not given. intervention. The results of the comparison of the psychological variables between the intervention group and the control group obtained a significance value of 0.000 and less than $0.05(\mathrm{p}<0.05)$, which indicates that the group given the intervention was more effective at improving psychology significantly than the group that was not given the intervention. The results of the comparison of the social variables between the intervention group and the control group obtained a significance value of 0.000 and less than $0.05(\mathrm{p}<0.05$ ), which indicates that the group given the intervention was more effective at improving social significantly than the group that was not given the intervention. The results of the comparison of the environmental variables between the intervention group and the control group obtained a significance value of 0.000 and less than 0.05 ( $p<0.05$ ), which indicates that the group given the intervention was more effective in improving the environment significantly than the group that was not given the intervention. The results of the comparison of the overall variable between the intervention group and the control group obtained a significance value of 0.000 and less than $0.05(\mathrm{p}$ $<0.05$ ), which indicates that the group that was given the intervention was more effective at increasing overall significantly compared to the group that was not given the intervention. The results of the comparison of the quality of life variable between the intervention group and the control group obtained a significance value of 0.000 and less than $0.05(\mathrm{p}<0.05)$, which indicates that the group given the intervention was more effective at improving quality of life significantly compared to the group that was not given intervention.

\section{DISCUSSION}

According to Seventina, H., (2019), said that health education is very influential on the level of knowledge, besides that health education can affect the level of knowledge so that it can have changes in healthy behavior. According to Bekele, B. B., (2020), said that Diabetes SelfManagement Education (DSME) has a positive impact on the level of self-management and quality of life in people with Diabetes Millitus and can reduce the risk of complications in Diabetes Millitus. Diabetes Self-Management Education (DSME) is a process of facilitating skills, knowledge and abilities in self-care or diabetes millitus self-management. According to Agustiningrum, R. (2019), in his research, he said that Diabetes Self-Management Education (DSME) is very effective for self-care in Diabetes Millitus patients. From the results of research conducted by researchers in the intervention group, Diabetes Self-Management Education (DSME) is a Diabetes Millitus health education method that is effective in increasing knowledge. Skills and abilities in self-management and quality of life in people with Type II Diabetes Millitus. From the results of research conducted by researchers in the intervention group, it is proven that they have knowledge, skills and abilities in self-management and experience improvement in selfmanagement and quality of life after being given the Diabetes Self-Management Education (DSME) health education method or program. Diabetes Self-Management Education (DSME) was able to improve self-management and quality of life in the intervention group so that there were significant changes in the level of self-management and quality of life in people with Type II Diabetes Millitus. According to Maulana (2019), one of the strategies in obtaining behavior change in people with Diabetes Millitus is by providing health information or education. The process of empowering or empowering people with Diabetes Millitus can be done by providing information or education such as health education in changing behavior and attitudes in order to achieve selfmanagement and a good quality of life. According to Notoadmodjo (2007), the level of education greatly determines a person's ability to understand the knowledge obtained, such as the higher the level of one's education, the more someone is willing to accept and understand information. Research conducted by Wiastuti (2017) states that high levels of education will tend to easily absorb health information so that it can change a person's behavior. According to Haas, (2014) in his journal entitled National Standards DSME is a process to facilitate the knowledge, skills, and abilities needed for diabetes self-care (Self-Management). This process combines the needs, goals, and life experiences of people with diabetes or prediabetes and is guided by evidence-based standards. The overall goal of DSME is to support decision making, self-care behavior, problem solving, and active collaboration with health care teams and to improve clinical outcomes, health status, and quality of life. 


\section{CONCLUSION}

Based on the results of the research that has been presented, Diabetes Self-Management Education (DSME) is proven to be effective in improving self-management and quality of life in Diabetes Millitus sufferers, Diabetes Millitus sufferers are able to determine the right nutritional diet, be able to exercise / physical activity, control blood sugar levels and being able to perform Diabetes Millitus health so that the treatment of Diabetes Millitus sufferers who have good levels of self-management and good quality of life. Diabetes Self-Management Education (DSME) can improve self-management and quality of life in people with Type II Diabetes Millitus. The results of the study showed that the intervention group that was given treatment or intervention proved to be very effective in improving self-management and quality of life and was inversely proportional to the control group that was not given treatmen.

\section{ACKNOWLEDGMENTS}

Researchers are grateful to all respondents who have been cooperative in participating in all research activities. Researchers and thanks to the related parties of the Kempo Health Center, Kempo District, Dompu Regency who have allowed researchers to carry out the process of research activities

\section{CONFLICTS OF INTEREST}

In the research that has been done, this research does not have a conflict of interest from other parties.

\section{REFERENCES}

Agustiningrum, R., Kusbaryanto, K., Keperawatan, M., \& Kedokteran, F. (2019). Efektifitas Diabetes Self Management Education Terhadap Self Care Penderita Diabetes Mellitus: A Literature Review. 6(2), 558-563

Bekele, B. B., Negash, S., Bogale, B., Tesfaye, M., \& Getachew, D. (2020). The effectiveness of diabetes self-management education ( DSME) on glycemic control among T2DM patients randomized control trial: systematic review and meta-analysis protocol

Maulana, H.DJ. (2019). Promosi Kesehatan. Jakarta: EGC

Haas. (2014). National Standar For Diabetes Self-Management Education of Support.Diabetes Care

Notoatmodjo, (2010). Prilaku Kesehatan. Jakarta: PT. Rineka Cipt

Pham, B. D., Kim, B. G., Nguyen, T. T. H., \& Hoang, V. M. (2019). Exposure to messages on risk factors for noncommunicable diseases in a rural Province of Vietnam. BioMed Research International, 2019. https://doi.org/10.1155/2019/7962947

Seventina, H., Tinggi, S., Kesehatan, I., Astrid, M., Concentration, M. S., Indonesia, J., Susilo, W. H., \& Lecture, R. (2020). Effect of Health Education and Diabetic Foot Exercise on Sensory Perception and Knowledge level of Patients With Type 2 Diabetes Mellitus in Cirebon District General Hospital in West Java Province. 27(ICoSHEET 2019), 362-365.

Whittemore, R., Vilar-Compte, M., De La Cerda, S., Marron, D., Conover, R., Delvy, R., LozanoMarrufo, A., \& Pérez-Escamilla, R. (2019). Challenges to diabetes self-management for adults with type 2 diabetes in low-resource settings in Mexico City: A qualitative descriptive study. International Journal for Equity in Health, 18(1), 1-10. https://doi.org/10.1186/s12939-0191035-x

Wiastuti Mariana Siti Rondhianto, Nur Widayanti. (2017). Pengarauh Diabetes SelfManagement Education and Suport (DSME/S) Terhadap Stres Pasien Diabetes Millitus Tipe II di Wilayah Kerja Puskesmas Patrang Kbaupaten Jember. Universitas Jember.Jember 
